\title{
Mapping the Locational Pattern of Hotels in Akure, Ondo State.
}

\author{
Babawale Akin Adeyemi, \\ Department of Geography, Adeyemi College of Education, Ondo, Nigeria
}

\begin{abstract}
The study analysed the locational pattern of hotels in Akure, Ondo State using GIS techniques. Data for the study were obtained from both primary and secondary sources. The coordinate of each of the hotels was captured using a handheld Global Positioning System (GPS) receiver which was used to create a point map. Secondary data included the road network map of Akure obtained from the Ondo State Ministry of Urban and Physical Planning and the list of hotels obtained from the Research and Statistics Department of the Ministry of Economic planning and budgeting. These data were processed and analyzed to generate a geospatial database for hotel facilities using ILWIS (3.3) and ArcGIS (9.3) G.I.S. Software. The result reveal that hotels were located in all parts of Akure with the Oke-Ijebu / Ijapo Estate axis located in the North Eastern part of Akure having the highest concentration of the hotels in them representing $31.3 \%$ of the hotels in the study area. It further reveals that few hotels were close to the central business district of the study area. The study concluded that GIS is a veritable tool which both individual and government can use to arrive at important decision-making on location of hotels which would give rise to the proper planning and management of hotels.
\end{abstract}

Keywords: Assessment, GIS, hotels, location pattern, mapping.

\section{Introduction}

The word Hotel means an establishment that provides lodging and usually meals, entertainment and various personal services for the public (Webster's dictionary, 2008). The hotel industry is an important special service providing sector in many countries especially those attracting a large tourist trade. Evidence of hotels and the hospitality industry have been recorded as far back as biblical times when Mary and Joseph arrived in Bethlehem during the census. As the Bible depicts, Mary and Joseph were refused accommodation because there was no room at the inn. Since the beginning of time, people have travelled for commerce, religion, family, health, immigration, education, tourism and recreation. The first inn located in America was recorded in the year 1607 and paved way for many others in the hospitality industry. The first publicly held hotel (the city Hotel) opened in New York in 1792. The first modern hotel (The Tremoat) opened in Boston in 1809 and the first business hotel (the Buffalo statler) opened in 1908.

From there a surge of hotels flooded America and the rest of the world including the Third World (the developing countries) with prominent names such as Radisson, Marriot and Hilton etc. To a layman, the word "hotel" in a developing country, means a brothel, which is mainly used for prostitution and liquor drinking. The hospitality industry provides services for people who are away from home regardless of whether it is for long or short periods of time. These services can vary according to the specific needs of both the person away from home and the organization operating those services (Baker et al, 2000)

The industry is important because it contributes to the growth of an economy by providing a lot of employment opportunities for the people, funding a large percentage of a country's Gross Domestic Product, thereby helping to raise the national income and by earning foreign currencies through the goods and services provided to foreign visitors, thus improving the balance of payments (Baker et al, 2005). There is no doubting that hospitality industry is the livewire of tourism at all levels. The United Nations World Tourism Organization (UNWTO) confirms that between $70 \%$ and $75 \%$ of international tourists' expenditure goes to hospitality services on annual basis (Akpabio, 2007). This confirms the strategic importance of the sector to tourism. It is estimated that there are over a million hotels in the United States of America. But in Nigeria, there are only about 12 internationally branded hotels (Amadi, 2008a). Nigeria has so few internationally branded hotels due to the former perception of the country as a high - risk destination for investments, especially in hotel businesses, which are capital intensive and require long - term for the investor to recoup his money. Investors in hotels hardly look towards Nigeria due to exorbitant cost of landed property and high lending rates in Nigerian banks. It is a lot easier and cheaper to acquire land and build a hotel in USA than it is in Nigeria (Amadi, 2008a). Lending rate in USA is about 6 per-cent with mortgage of about 25 years in which investor has to pay back the 
money. But in Nigeria, the lending rate could go as high as 25 per-cent, depending on who is borrowing and for what purpose. Additionally, Nigerian banks will only give the investor about three years to pay back.

The Nigerian hospitality industry is faced with a lot of problems. Among them are: high hotel charges and the slow pace on developing tourist sites that dot the various parts of the country (Akpabio, 2007). Others are erratic power supply (Amadi, 2008a), poor services (Nwosu, 2008a) and unethical behaviors by professionals in the industry (Awoseyin, 2007). In spite of these shortcomings, the hospitality industry in Nigeria contributed N680.1 million to the Nigerian economy in 1980, N492.4 million in 1984 (using 1984 constant basic prices for both periods), N477.9 million in 1990, N591.9 million in 2000 (CBN, 2003), N1950.0 million in 2004 and N2, 390.0 million in 2006 (using1990 constant basic prices) (CBN, 2006).

Hotels are spatially located in different areas for different reasons. The location of hotels in a particular area to a large extent is influenced by the presence of some activities or major tourist centres. The issue of the spatial distribution of hotel requires the use of digital mapping and Geographic Information System (GIS) and this study aims to use this technique in assessing the spatial location of hotels in the study area.

\section{Statement of the problem}

Location is one of the most important decisions for lodging firm. Of the four major marketing considerations; price, product, promotion and place, place and product have shown to be the most important for multi-site firms with price and promotion playing secondary roles (Langeard and Eiglier, 1983). All hotel chains search for ideal locations and, in many cases, compete against each other for the same sites. A hotel that can pick good sites more accurately and quickly than its competitors has a distinct competitive advantage (James and Sheryl, 1990). Based on efficiency explanations, spatial economics models generally predict clustering rather than dispersion of firms with similar market domains. Geographic clustering of competing firms was first modeled by Hotelling (1929). Subsequently, clustering was also supported by extensions of his model to the Lancasterian space of product characteristics. Other researchers, however, found that the clustering result was sensitive to the assumptions made by Hotelling (Graitson 1982), in particular to the existence of relocation cost. There is a large and growing empirical study on the productivity advantages of hotels located in a center of activity (Aberg 1973; Ciccone and Hall 1996; Henderson 1986, 2000; Moomaw 1981, 1988; Nakamura 1985; Sveikauskas 1975; Tabuchi 1986).

Previous studies have already described how hotel location and distribution evolve with urban development in cities (Wall et.al., 1985; Broadway 1993; Burtenshaw, Bateman and Ashworth 1981; and Pillen 1995). Along the same line, other researchers applied Ashworth and Tunbridge's model of urban hotel location. Among them are Weaver (1993) in the Caribbean; de Bres (1994) in small-town Kansas; Be'gin (2000) in Xiamen; and Shoval and Cohen-Hattab (2001) in Jerusalem. Although, these researchers applied Ashworth and Tunbidge's model of urban hotel location, the researchers failed to assess how location determines patronage. Peace (1987a) found that many of the city's hotels were clustered near the centre of the city, in Christchurch, New Zealand, but many of the newer ones have built in a linear fashion along the main highway axes. The study further revealed that small motels were located in the city core because they were unable to bear high cost of central city rents.

Inspite of the growing work on urban tourism, much of the work has focused upon cities in the western world. There is a dearth of studies of urban tourism, especially the spatial distribution of tourist support services in sub-saharan when compared with other major regions of the world. David and Katherine (1995) opined that the sub-standard performance of the sub-saharan tourism industry accounts for the relative dearth of academic literature in this area, as compared with other major world regions. Based on the above scenario, the study is set to apply (GIS) to the location of hotel in the study area.

\section{Methodology}

Data were collected from primary and secondary sources. The primary data include the geographic identification of all hotel facilities in Akure. This was obtained with a handheld GPS reading of the geographical coordinates (Latitude and Longitude) of each hotel. Sixty-four (64) hotels were identified and captured in the study. The secondary data includes the map of Akure that was obtained from the Ondo State Ministry of Urban and physical planning. A handbook containing the list of hotels in the study area with their address was obtained from the Research and Statistics Department of the Ministry of Economic Planning and Budgeting and the Ondo State Tourism Board. According to ODSG (2010), there are sixty-five hotels in Akure; this study was carried out using all the hotels listed in the research carried out by ODSG. The analogue road map of Akure obtained from the Ondo State Ministry of Urban and Physical Planning was scanned in Tiff format and loaded into ILWIS 3.2 Academic software by activating image reader extensions. After loading the map into the ILWIS 3.2 , it was registered to conform to UTM coordinate system with a sigma of 0.459 pixels. Prior to this, coordinates of seven established control points were recorded during the field ground truthing, using Garmin 
GPS hand receiver configured and projected to Universal Traverse Mercator Zone 31, using Clarke 1884 with Minna as the Datum. Using the above information, the coordinates for the map was determined.

After the map has been geo-referenced, it was exported to ArcGIS 9.3 software environment. It was from this environment that on-screen digitizing was carried out. Details on the images were traced out in segments as lines. This was done by creating a layer for the theme. Cleaning of the spatial data was carried out by checking on self-overlap, code consistency, dead ends and intersection among the digitized themes. After this had been done, the themes were exported to shapefile format. Within ArcGIS 9.3 the themes was added to a view, where further spatial analysis was carried out. The coordinates of hotels captured with a handheld GPS were downloaded from the GPS to ArcMAP 9.3 which allowed for the graphical display of these spatial entities as themes. These coordinates were used to create a point map which was overlaid on the digitized map of the study area to show the spatial pattern of the hotels.

\section{Result and discussion of finding}

Figure 1a shows the spatial distribution of these hotels in Akure. As shown in the Figure, all areas in the study area are served with hotels though the concentration differs from one location to the other. The figure further shows that most of the hotels are located outside the central business district of Akure. This is as a result of the fact that most area around the CBD had been developed and the cost of getting land around the CBD is highly exorbitant. Therefore, most hotel operators prefer to site their hotels in areas where cost of land was affordable except for few ones that have enough capital to purchase land around the CBD. Figure $1 \mathrm{~b}$ shows the clustering pattern of hotels in the study area. The figure shows that the Oke-ijebu / Ijapo axis located in the North Eastern part of Akure had the highest number of hotels in them representing 31.3\% of the hotels in the study area. This is so because this axis is a major residential area in Akure and there is an express road linking the two areas together which allows patrons easy access to the area.

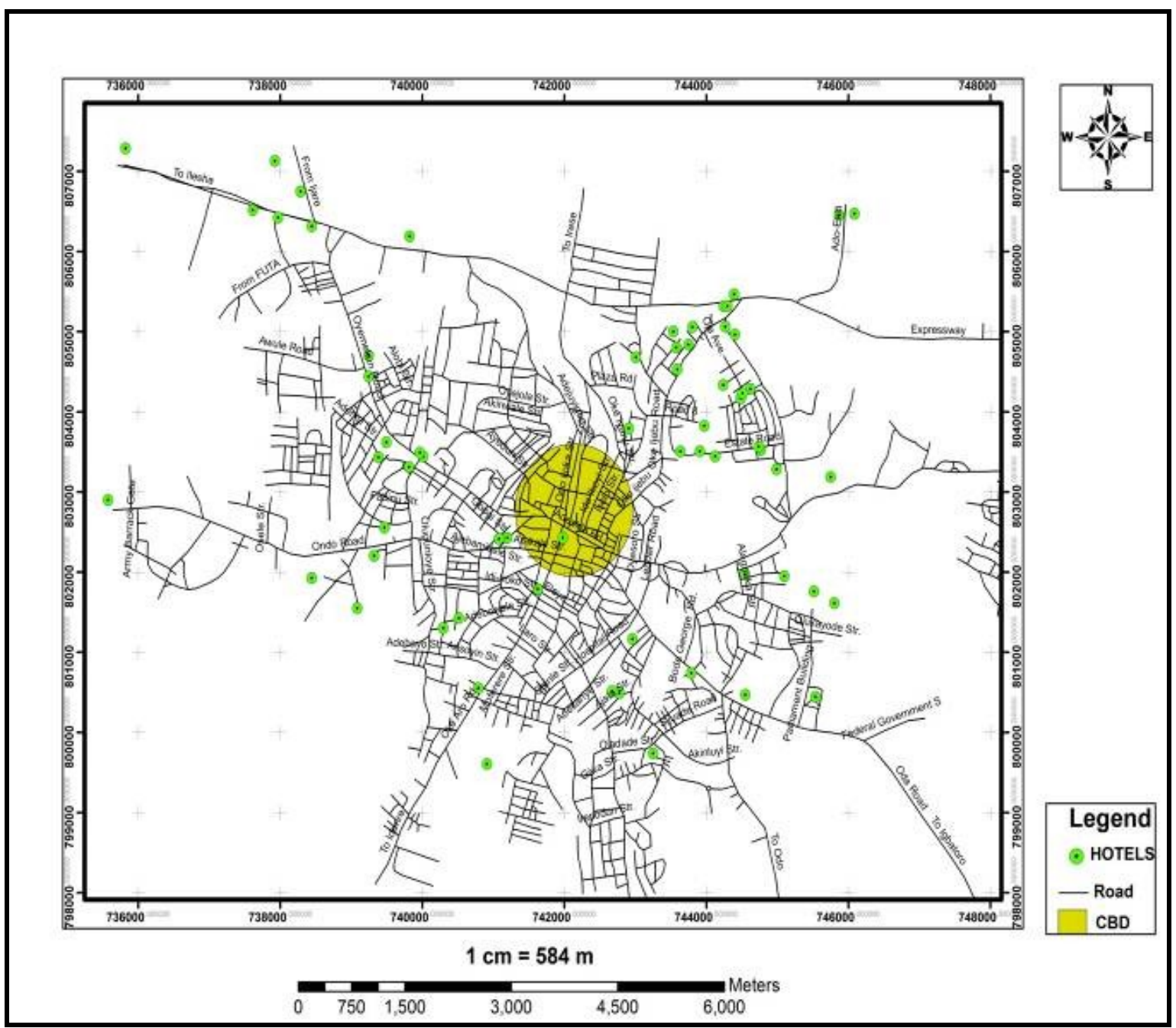

Figure 1a: Map showing the spatial distribution of hotels in Akure.

Source: Fieldwork, 2012. 


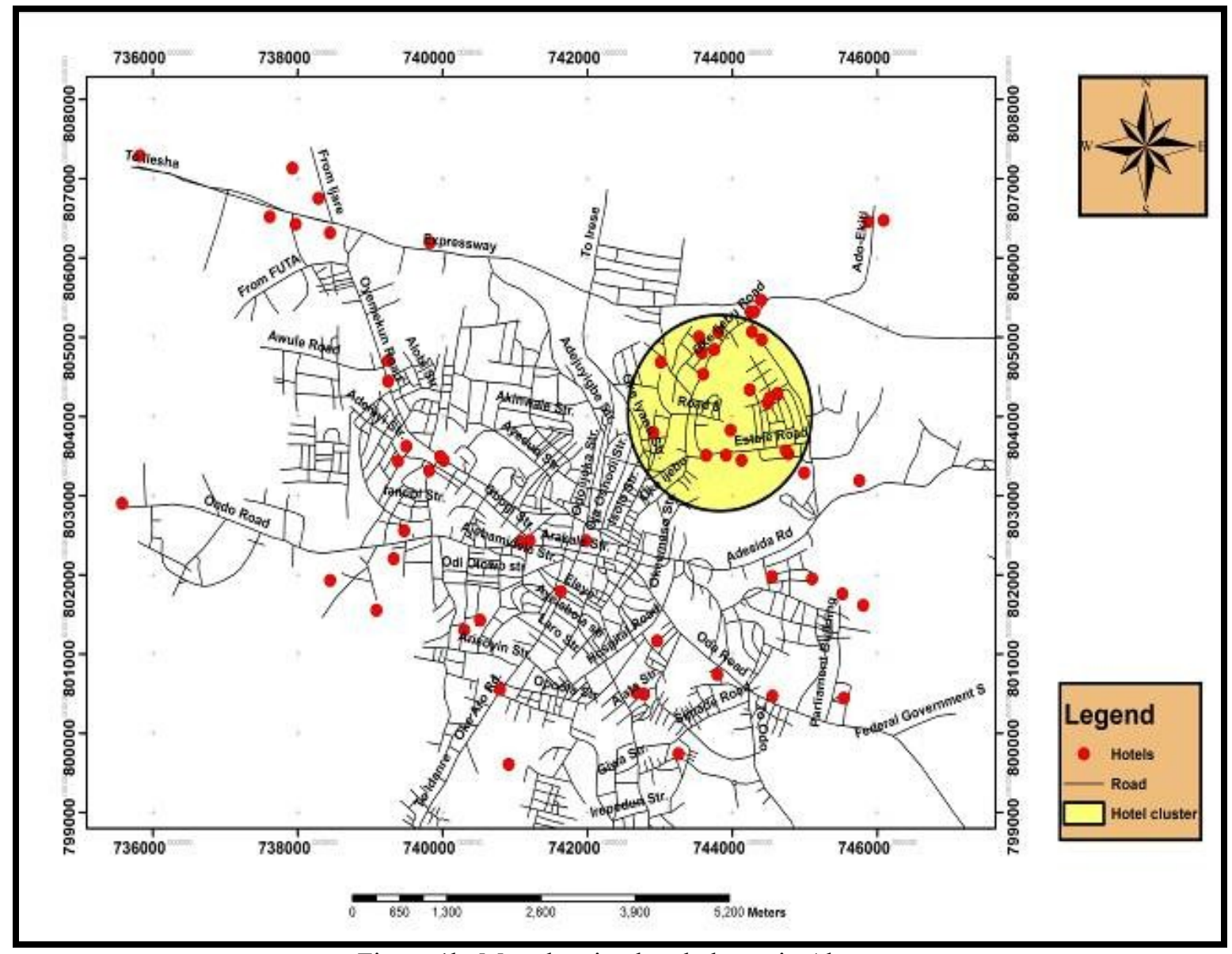

Source: Fieldwork, 2012

Figure 1b: Map showing hotel cluster in Akure.

\section{Conclusion}

This study identified and assessed the spatial distribution and patronage pattern of hotels in Akure South Local Government Area of Ondo State. It was discovered from the study that 64 out of the 65 hotels were operational at the time of the study. One of the hotel namely Alpha motels had gone into extinction as a result of road construction along the area. Almost all the areas in Akure are served with at least one or more hotels. This makes hotels to be evenly distributed. Moreover, the study found that most of the highly rated hotels were found clustering together around the Government Residential Area (G.R.A) and the Ijapo Estate Axis of the study area. This supports the claim of Ashworth and Tunbridge (1990) model of urban tourism which propounded that hotel of similar type tends to cluster and that hotels are found along main access roads. In the study, the hotels shows a pattern of clustering along major roads as put forward by the model and that similar hotel types also cluster around the same area. This allows for an healthy rival or competition amongst the hotels as stated by Hotelling (1929) which gives room for the sustainability of the hotels and helps in the marketing of the hotels. The OkeIjebu / Ijapo Estate / Alagbaka GRA axis of Akure could be referred to as the Recreation Business District because majority of the hotels in the study area were found along that axis. This is because the region is a public housing district developed by public initiative and in strict compliance with development control ethics. This has aided the hotels in locating their business in the region.

\section{References}

[1]. Aberg, Y. (1973): Regional productivity differences in Swedish Manufacturing. Regional and urban Economics 3:131-156

[2]. Akpabio, I (2007): Hospitality industry in Nigeria: Prospects and challenges in developing tourism, African Hospitality and Tourism, Vol 11, No 3, pp. 23-26.

[3]. Amadi, O. (2008a): Nigeria hotels and boom in tourism, Business day Newspaper, September 7, P9.

[4]. Awoseyin, L. (2007): Professional ethics in hospitality and tourism, African Hospitality and Tourism, Vol 11, No3, pp. 18-22.

[5]. Baker, S, Bradley P and Huyton (2000): Principles of Hotel Front Office Operations, Second Edition, London, Continuum, pp. 2, 6.

[6]. Begin, S. (2000): The Geography of a tourism Business: Hotel Distribution and Urban Development in Xiamen, China. Tourism Geographies 2:448-471

[7]. Broadway, M. (1993): Montreal's Changing Tourist Landscape. Canadian Journal of Urban Research 2:30-48

[8]. Burtenshaw, D., M. Bateman, and G. Ashworth (1981): The City in West Europe. Chichester: Wiley.

[9]. CBN (2003): Statistical Bulletins, Abuja, CBN, pp 1, 3-7. 
[10]. CBN (2006): Annual Report and Accounts for the year ended 31 st December 2006, Abuja, CBN, P229.

[11]. Ciccone, A., and R. Hall (1996): productivity and the Density of Economic Activity. The American Economic Review 86(1): 54-70.

[12]. David, W., and Katherine E. (1995): Spatial Patterns and Problems in Namibian Tourism. The Geographical Journal Vol 162, No 2, pp. 205-217.

[13]. De Bres, K. (1994): Cowtowns or Cathedral precints? Two models for contemporary urban tourism. Area, 26, pp 57-67.

[14]. Henderson, J. (1986): Efficiency of Resource Useage and City Size. Journal of Urban Economics 19: 47-70.

[15]. Henderson, J. (2000): Marshall's Scale Economies. Journal of Urban Economics 53: 1-28.

[16]. Hotelling, H. (1929): Stability in Competition. Economic Journal 39:41-57.

[17]. James, A.F and Sheryl, E.K (1990): Selecting Profitable Hotel Sites at La Quinta Motor Inns. Interfaces, Vol 20 No 2, pp. 12 -20.

[18]. Langeard, E. and Eiglier, P. (1983): "Strategic management of service development", in Berry,L.L. et al. (Eds), Emerging Perspectives on Services, AMA, Chicago, IL, pp. 68-72.

[19]. Moomaw, R. (1981) Productivity and City Size: A Critique of the Evidence, Quarterly Journal of Economics 96:675-688.

[20]. Moomaw, R. (1988): Agglomeration Economies: Localization or Urbanization? Urban Studies 25:150-161.

[21]. Mostafa A. (2003): Crime Mapping and Spatial Analysis. M.Sc. Thesis, ITC, Netherlands.

[22]. Nakamura, R. (1895) Agglomeration Economies in Urban Manufacturing Industries: A Case of Japanese Cities. Journal of Urban Economics 17:108-124.

[23]. ODSG (2010): Report of the Statistical Survey of hotels and Tourist Centre in Ondo State. Conducted by Research and Statistic Department, Ministry of Economic Planning and Budgeting, Akure.

[24]. Pearce, D.G. (1987b): Tourism Today. A Geographical Analysis.London:longman.

[25]. Pillen, P. (1995): Les Mutations Recentres dans le Paysage Hotelier Bruxllois. Revue Belge de Geographie 119:357-368.

[26]. Shoval, N., and K. Cohen-Hattab (2001): Urban Hotel Development Patterns in the Face of Political Shifts, Annals of Tourism Research 22:908-925.

[27]. Sveikauskas, L. (1975): The Productivity of Cities, Quarterly Journal of Economics 89:393-413.

[28]. Tabuchi, T. (1986): Urban Agglomeration Economies, Capital Augmenting Technology, and Labor Market Equilibrium, Journal of Urban Economies 20:211-228.

[29]. Wall, G., Dudycha, D., \& Hutchinson, J. (1985): Point Pattern Analyses of Accommodation in Toronto, Annals of Tourism Research 12:603-618.

[30]. Webster, Noah: Webster's Dictionary 1913 (original .RB), v2, 04 Nov 2008

[31]. Weaver, D. (1993): Model of Urban Tourism for Small Caribbean Islands, Geographical Review 88:134-140. 